\title{
Recenzje
}

DOI: $10.14746 /$ por.2018.1.23

\section{NIENAPISANA KSIĄŻKA MIŁOSZA O ROSJI}

\author{
Ewa PogonowsKa ${ }^{1}$
}

Szumna, Małgorzata. Przymus powtórzenia. Wątki rosyjskie w eseistyce Czesława Miłosza. Kraków: Universitas, 2018. 252 S.

Wybór tekstów Czesława Miłosza o Rosji zebrany w dwóch tomach - które starannie opracowała Barbara Toruńczyk ${ }^{2}$, zaś kompetentnymi wstępami opatrzyli Clare Cavanagh (t. I) i Marek Kornat (t. II) - jest, moim zdaniem, pozycją wydawniczą nie do przecenienia, bardzo ważną lekturą zarówno dla miłośników twórczości polskiego noblisty, jak i dla tropicieli "spraw rosyjskich" w literaturze polskiej. Antologia ukazała się kilka lat temu (2010 i 2011) i zdążyła przez ten okres zainspirować do refleksji nie tylko literaturoznawców.

Nie bez powodu od przywołania zredagowanego przez Toruńczyk wyboru szkiców poety, sygnowanych tytułem Rosja. Widzenie transoceaniczne, rozpoczęłam prezentację książki Małgorzaty Szumnej. ${ }^{3}$ Autorka rozprawy Przymus powtórzenia. Watki rosyjskie w eseistyce Czestawa Miłosza we wzmiankowanej antologii - jak wynika z rozdziału pierwszego - znalazła bodziec do swych naukowych studiów. Sposób ujęcia przez nią tematu może jednak zaskoczyć czytelnika, który spodziewałby się li tylko pogłębionych komentarzy do dyskursu eseisty tudzież rozwinięcia wątków podjętych przez Cavanagh i Kornata. Otóż Szumna zwraca uwagę na szczególny aspekt Miłoszowych narracji o Rosji, który oba tomy Widzeń transoceanicznych bezwiednie uwypukliły. Kwestię tę autorka zasygnalizowała już w tytule

1 E-mail: e.pogonowska@poczta.umcs.lublin.pl

2 Chciałabym podkreślić, że inspiratorką antologii była Monika Wójciak, która o swoim pomyśle wspominała już na marginesie swojej książki: „'Rosyjskie teksty' Miłosza warto więc byłoby, jak sądzę, zebrać w jedną całość. Tym bardziej że prezentują złożony, ale jednocześnie niezwykle spójny, konsekwentny, rzeczowy stosunek poety do kultury, literatury, historii i filozofii rosyjskiej" (Wójciak 136).

3 Książka Szumnej jest wersją rozprawy doktorskiej napisanej pod kierunkiem prof. Jerzego Jarzębskiego. 
swej książki, by dalej stwierdzić: „Rosyjskimi tekstami poety rządzi powtórzenie, powiem więcej: obsesyjny wręcz przymus powtórzenia ${ }^{4}$, który skłonna byłabym uznać za najważniejszy punkt wyjścia przy jakiejkolwiek ich interpretacji" (Szumna 12). Badaczka skoncentrowała się na sensie owych repetycji, próbując dowieść, że są one przemyślanym zabiegiem konstrukcyjnym, „świadectwem myśli uporczywie krążącej" wokół ważkich i trudnych zagadnień o charakterze uniwersalnym. Tę właściwość dzieła Miłosza można zaobserwować nie tylko w odniesieniu do wątków rosyjskich, czego Szumna ma świadomość. Przywołam w tym miejscu konstatację Jana Błońskiego, który w rozmowie z Tomaszem Fiałkowskim i Andrzejem Franaszkiem stwierdził: „Miłosz rzadko odkrywa: on raczej przypomina, uzupełnia, rozwija. Ma swój kapitał, niesłychanie bogaty, który ciągle na nowo wykorzystuje i przepracowuje. Jego sztuka, jego sekret to umiejętność odnawiania" (Błoński 394).

Według Szumnej fakt, że autor Rodzinnej Europy nie wydał oddzielnej książki poświęconej Rosji, ma swe uzasadnienie. Problematyka ta bowiem nie funkcjonuje w jego pisarstwie odrębnie, samoistnie. Postrzegany z tej perspektywy wybór tekstów wydanych przez Zeszyty Literackie odsłania - jej zdaniem - swe niedostatki wynikające $\mathrm{z}$ ograniczeń wpisanych zresztą $\mathrm{w}$ poetykę antologii. Literaturoznawczyni konstatuje:

Znaczenie rosyjskich esejów Miłosza widoczne jest dopiero wtedy, gdy pokażemy je $\mathrm{w}$ dialogu z innymi zasadniczymi liniami jego estetyki, gdy nie będziemy czytać ich $\mathrm{w}$ oderwaniu. [...] Wyjęcie tych szkiców $\mathrm{z}$ ich macierzystego kontekstu oznacza więc mimo wszystko! - swego rodzaju amputację, którą usprawiedliwiać może tylko wysiłek odnalezienia nowych kontekstów dla Miłoszowej myśli, niezarysowanych wystarczająco jasno w jego twórczości (Szumna 16).

Moim zdaniem badaczka nie docenia naddanego niejako celu większości tego typu almanachów, które zachęcić mogą potencjalnego, zafrapowanego wybranym wątkiem czytelnika do sięgnięcia po teksty źródłowe i poszerzenia horyzontów swej lektury. Zwłaszcza że wybór Toruńczyk (oparty również na tekstach rozproszonych w czasopismach) zawiera materiał bardzo bogaty i różnorodny, który pokazuje złożoność i wielowymiarowość refleksji Miłosza na temat Rosji. Ponadto na - poniekąd słuszną - sugestię autorki, że eseje złożone w jeden tom mogą (przynajmniej w pierwszym odczytaniu) nużyć odbiorcę wielokrotnością powtórzeń, chciałoby się przypomnieć refleksję Andrzeja Kijowskiego ze szkicu poświęconego Antoniemu Słonimskiemu: „Owszem, powtarzał się, ale skutek jest taki, że teraz, kiedy go już nie ma, mamy głowy nabite tym, co mówił” (Kijowski 112).

4 Wszystkie podkreślenia zaznaczone wytłuszczeniem moje - E.P. 
Słowem, z jednej strony Szumna docenia wartość pracy redakcyjnej Toruńczyk i jej zespołu, z drugiej zaś, uwzględniwszy ukierunkowujące lekturę wstępy Cavanagh i Kornata, wskazuje na mankamenty czy raczej jednostronność tego zamysłu, która miałaby się przejawiać w nadmiernym wyeksponowaniu politycznego, a ściślej sowietologicznego wymiaru „Rosji Miłosza”. Uczynienie Zniewolonego umystu „wytrychem” (określenie autorki) do twórczości poety uniemożliwia oddanie wieloaspektowości i nieoczywistości tej eseistyki. Istotnie, Miłosz dość sceptycznie odnosił się do absolutyzowania roli tego tomu esejów w jego dorobku, ale też - podkreślę - wskazywał na niedostrzegany aspekt swych szkiców, gdy zaznaczał w rozmowie z Aleksandrem Fiutem, że zawarta tam analiza „wykracza poza problematykę komunizmu. To jest książka w dużym stopniu filozoficzna [...]" (Fiut 51). I oto Szumna, czytając teksty Miłosza o Rosji, powzięła zamiar wyjścia poza zagadnienia historyczno-polityczne, aby pokazać, co się (jeszcze) za owymi rosyjskimi wariacjami kryje. Badaczka podkreśla:

Osobiście sądzę bowiem, że to mniej interesująca część propozycji Miłosza, mająca charakter bardziej doraźny. W konsekwencji ciekawsze wydaje mi się odmienne postawienie sprawy: czytanie jego eseistyki tak, jakby była ona przezwyciężeniem ograniczeń Zniewolonego umystu, wskazanie innych ścieżek, które w nim się jeszcze nie pojawiały (Szumna 21).

Przeciwwagę dla Zniewolonego umystu powinna stanowić, zdaniem Szumnej, Ziemia Ulro, książka uwidaczniająca doniosłe znaczenie problematyki religijnej, metafizycznej w twórczości Miłosza ${ }^{5}$, również w odniesieniu do tematów rosyjskich. Wobec powyższego autorka z przekonaniem konstatuje:

Brakuje w propozycji Toruńczyk zwrócenia uwagi na fakt, że Miłosz pozostaje w tych esejach bardzo często po prostu myślicielem religijnym. Wymiar ten jednak bardziej jest dojmujący właśnie wtedy, gdy czytamy go w całości; odłożenie na bok tego kontekstu faktycznie może sprawiać (mylące, jak sądzę) wrażenie, że podstawowa jest tu historyczna dominanta. Myślę, że można poprzez Miłoszowską próbę lektury Rosjan pokazać, jak się ten metafizyczny temat usamodzielnia (Szumna 22).

Szumna obiecuje, że w swym studium odsłoni zagadnienia mniej eksploatowane interpretacyjnie, i zapowiada wyzyskanie tekstów (nie tylko eseistycznych) bądź mało znanych, bądź niedrukowanych (przeprowadza owocną kwerendę w Yale University, czytając między innymi manuskrypty wykładów o Dostojewskim),

5 Sam Miłosz zaznaczał, że jego ukrytą intencją było to, aby Ziemia Ulro stanowiła („w pewnym sensie") dalszy ciąg Zniewolonego umystu. We wcześniej napisanej książce zajmował się skutkami, zaś później postanowił cofnąć się do źródeł (Miłosz 2013: 11). 
choć nietrudno zauważyć, że bardzo ważny, o ile nie podstawowy, materiał źródłowy, którym się posługuje, stanowią klasyczne przecież utwory autora Rodzinnej Europy. Badaczka zastosowaną przez siebie metodę określa jako krytyczną hermeneutykę. Za cel stawia sobie uchwycenie spraw nie zawsze czytelnych, problematycznych - w kontrze nie tylko do innych badaczy, ale także samego Miłosza, wobec którego stosuje metodę „kontrolowanej nieufności”. Pisze ona, że pragnie poddać "podejrzliwej lekturze" deklaracje i autokomentarze poety nie po to, by wytknąć mu przekłamania i nieścisłości, „lecz by uchwycić podskórny nurt tej myśli, rządzące nią zasady, które nie do końca i nie zawsze były dla piszącego jasne" (Szumna 32). Siłą rzeczy ostatnia deklaracja sugerować by mogła zacięcie psychoanalityczne w podejściu do utworów noblisty. Choć nie o to raczej autorce chodziło. Przekonuje mnie konkluzja naukowego wywodu Szumnej, która pisze, że „rosyjskie teksty Miłosza mają charakter wariacji i taki sam charakter muszą mieć ich interpretacje: tak, jak kapryśna bywa niekiedy myśl eseisty, tak i rzutka musi się starać być myśl komentatora”. I dodaje za Krzysztofem Mętrakiem, że Miłosz przez swe dzieło „wciąż nam powtarza, że 'a jest a' i 'a nie jest a' i drwi dobrodusznie z naszej potrzeby jednoznaczności” (Szumna 216). Pozwolę sobie w tym miejscu przypomnieć słowa samego poety, który zdradzał specyfikę swojej strategii literackiej, podkreślając (w Rodzinnej Europie), że jego umysł „lubował się w sprzecznościach": "Jedną z moich literackich rozrywek było prowadzić czytelnika w jakimś kierunku i następnie poplątać mu ścieżki, tak żeby stracił pewność, co zresztą powodowało wiele nieporozumień" (Miłosz 1990: 123). Przychodzi mi również na myśl poetycka konstatacja (z Traktatu teologicznego), , [...] że taka jest zasada poezji, / dystans między tym, co się wie, / i tym, co się wyjawia" (Miłosz 2011b: 1262). Wydaje się, że tego rodzaju sugestie samego pisarza uzasadniają „podejrzliwą" (a przynajmniej czujną) lekturę jego pism, jaką zaproponowała krakowska literaturoznawczyni.

Wątpliwości moje budzi natomiast enuncjacja autorki, że jej propozycja interpretacyjna będzie odmienna od stanowisk prezentowanych przez innych badaczy. Nie chodzi oczywiście o krytykowanie budzącej szacunek próby poszukiwania nowych tropów przy eksplikacji wątków rosyjskich u Miłosza - to Szumnej udaje się doskonale - ale o brak syntezy stanu badań. Nie wyczerpuje tego pokaźna bibliografia, skoro głosy innych badaczy zostają nieraz skwitowane przypisem. Wydaje mi się, że dla wielu czytelników taka „odtwórcza” narracja (a takiej - trzeba przyznać - literaturoznawczyni zdecydowanie unika) wzbogaciłaby lekturę książki o Przymusie powtórzenia... Zwłaszcza że próby dotarcia do Rosji Miłosza w aspekcie ponadhistorycznym, a więc wątki obecne w książce Szumnej, choć zapewne nie tak systematycznie i konsekwentnie przedstawione, już się pojawiały. Usprawiedliwia literaturoznawczynię wybór strategii w jej, skądinąd, bardzo dojrzałym, dyskursie naukowym; autorka dąży przede wszystkim do eksplikacji założeń i do syntezy, pomija zaś to, co mogłoby „rozwadniać” przyjętą przez nią koncepcję. 
Podstawowe informacje, które nadają profil jej rozważaniom miłoszologicznym, Szumna zamieściła w pierwszym rozdziale książki („Godna podziwu monotonia". Miejsce powtórzenia w rosyjskiej refleksji Miłosza), który - skoro wstępu w ścisłym znaczeniu tego słowa rozprawa jest pozbawiona - zdaje się pełnić funkcję wprowadzenia. W nocie bibliograficznej autorka informuje o pierwodrukach niektórych fragmentów pracy. Zręcznie jednak zostały one wkomponowane w całość (ujednolicone $\mathrm{w}$ trybie przekazu), zatem logika wywodu jest nienaganna, a klarowna kompozycja umożliwia przejrzystą prezentację wyników badań. Książkę dobrze się czyta, gdyż jest ze znajomością rzeczy i z wprawą napisana, wyrazista w przekazie, bo dobrze eksponująca prymarne tezy i przekonania autorki, nierzadko odważne i dyskusyjne. Trudno nie zauważyć, że badaczka wierna jest wybranej metodzie i raczej niewzruszona w obronie swego stanowiska. Tym, co chyba najbardziej może absorbować czytelnika w książce Szumnej, jest poszukiwanie nowych, nieprzetartych lub nie dość wydeptanych ścieżek interpretacyjnych w sytuacji - rzekłabym mało luksusowej, bo trudno wymienić bardziej obudowaną literaturą przedmiotową twórczość współczesnego pisarza.

Jak się rzeczone poszukiwania realizują? Spróbuję się temu przyjrzeć, siłą rzeczy uwzględniając tylko wybrane motywy tematyczne wywodu, choć - mam nadzieję reprezentatywne. $W$ pięciu następnych rozdziałach literaturoznawczyni rozwija swą myśl, akcentując sprawy szczególnie istotne w rozpoznaniach wątków rosyjskich w eseistyce (i innych przekazach) Miłosza. Stara się być wierna założeniu, że dobra interpretacja "powinna na plan pierwszy wysuwać nie to, co jednoznaczne, lecz pęknięcia i nieciągłości" (Szumna 30). Taka strategia lektury wydaje się zgodna z zamysłem samego poety, jego wymaganiami wobec projektowanego odbiorcy swego niestroniącego od sprzeczności i niedopowiedzeń, zawsze "niegotowego" dzieła otwartego. Kluczowe dla Szumnej okazuje się zapytanie o to, czy - w odniesieniu do twórczości Miłosza - „istnieje sposób na rozdzielenie refleksji poświęconej komunizmowi oraz Rosji jako takiej" (Szumna 21). Literaturoznawczyni konstatuje: „Miłosz-sowietolog (nawet tam, gdzie poza granice sowietologii wykracza, obudowując swoje uwagi o wiele głębszym niż zazwyczaj komentarzem) nie do końca jest tożsamy z Miłoszem piszącym o myśli rosyjskiej" (Szumna 22). W związku z powyższym, opcja przyjęta przez autorkę ma unaocznić, że refleksja autora Ziemi Ulro nad kulturą rosyjską prowadzi do podjęcia problematyki uniwersalnej, co oznaczałoby między innymi diagnozowanie istoty przemian mających miejsce na Zachodzie. W kontekście tego prymarne stawałoby się zagadnienie obecności vs. nieobecności Boga w świecie. Badaczka próbuje w pewnej mierze oddzielić Miłosza metafizycznego od historycznego/politycznego. Chociaż - czego dowodzi tok jej wywodu - zdaje sobie sprawę, że te dwa wymiary twórczości autora Kronik nierzadko łączą się (względnie sąsiadują) ze sobą, bo jak syntetycznie ujął to Marian Stala: „na pytanie, postawione w języku polityki czy historii, znaleźć można u Miłosza odpowiedzi w języku teologii" (Stala 61). 
W drugim rozdziale książki (Miłosz i Muлou. Autobiografia fantazmatyczna) autorka pochyla się nad utworami Miłosza, które mają wyraźnie autobiograficzny wydźwięk. Nie zatrzymuje się jednak przy kwestiach poetologicznych, by przypatrywać się różnym obliczom autobiografizmu, swoistego zwłaszcza w tekstach eseistycznych, z natury chimerycznych i wieloznacznych. Skupia się przede wszystkim na próbie odpowiedzi na pytanie, „w jaki sposób pisanie o Rosji stało się dla Miłosza sposobem na konstruowanie własnej autobiografii fantazmatycznej" (Szumna 39). W tym celu odczytuje na nowo oddzielone prawie trzydziestoletnim dystansem czasowym oraz posiadające odmienną strukturę genologiczną tomy Rodzinna Europa (pierwodruk 1958) i Kroniki (pierwodruk 1987)6. Szumna sięga w swych dociekaniach do założeń antropologii fantazmatu wyłożonych w Projekcie krytyki fantazmatycznej Marii Janion (Janion 7-29). Zastanawia się nad tym, jakie próby podejmuje poeta $\mathrm{w}$ celu definiowania czy może konstruowania własnej tożsamości. Rodzinna Europa w takim oglądzie jawi się jako opowieść zarówno o wtajemniczeniu w historię, jak i o inicjacji w lęk. Na przekór samemu poecie Szumna twierdzi, że Rosji Miłosz „nigdy naprawdę nie dotknął”, lecz de facto ją sobie wymyślił, „na dziecięce wspomnienia nadpisując późniejszą wiedzę" (Szumna 43). Oznacza to, że drugie dno Miłoszowych wynurzeń stanowią treści wyparte, fantazmaty. Wedle badaczki w zbiorze szkiców o „rodzinnej Europie” ujawnia się - w dużej mierze konglomerat polskich lęków, mitów czy wręcz stereotypów. Taką prawdę o Rosji sankcjonować miały w szkicu Miłosza słowa przeczytane u Mickiewicza czy de Custine'a ${ }^{7}$. Warto przypomnieć, że eseista - świadom swej stronniczości - wyraźnie eksponował w eseju Rosja swe stanowisko, pisząc: „Czy jestem sprawiedliwy, czy nie, odsłaniam przynajmniej swoją obsesję” (Miłosz 1990: 151). „'Głębia' literatury rosyjskiej była dla mnie zawsze podejrzana" - pisał dalej, co przecież nie przekładało się na jego późniejsze studia. Dwa lata po opublikowaniu Rodzinnej Europy kreślił następujące słowa w liście do Andrzeja Walickiego: „Może nie powinienem był pisać tego rozdziału o Rosji, ale musiałem, z nieprzezwyciężonej wewnętrznej potrzeby, żeby kompleks obnażyć i ewentualnie potem przejść $\mathbf{w}$ jakąś wyższą faze" (Walicki 408).

W wyrazisty i przekonujący sposób Szumna ukazuje, jak z Rodzinnej Europy wyłania się "spowiedź dziecięcia wieku”, jak przez jednostkową biografię urodzonego na Litwie poety wybrzmiewa głos pokolenia - wreszcie - jak odbywa się konstruowanie polskiej tożsamości w kontrze do tego, co rosyjskie. Badaczka sugestywnie uwidoczniła, że w Kronikach (zwłaszcza w cyklu Dla Heraklita) Miłosz zmienia perspektywę: odrywa swe myślenie o Rosji od polskich uwikłań, uniwersalizuje je.

6 W Erracie dołącza: Zaczynając od moich ulic, Abecadło i O podróżach w czasie.

7 Irena Grudzińska-Gross, zestawiając ze sobą La Russie en 1839 Custine'a i „Ustęp” III części Dziadów Mickiewicza, pisała: „Różnicę między tymi dwoma utworami można porównać do Puszkinowskiego romantycznego przeciwstawienia Mozarta i Salieriego. Niesłychane podobieństwo tematyczne, geniusz jednego, pracowitość drugiego..." (Grudzińska-Gross 214). 
Przy interpretacji wiersza Trwoga - sen literaturoznawczyni skupia się na wyakcentowaniu motywu potencjalnej utraty tożsamości, co rodzi pytanie, „kim byłby rosyjski poeta Miłosz?" (Szumna 65). W Kronikach, co słusznie podkreśla badaczka, podjęte zostały problemy, których próżno by szukać w Rodzinnej Europie. Z perspektywy końca wieku doświadczony poeta przygląda się La Belle Époque i nieświadomej niczego Europie, gdy "paryska bohema uczyła się zagadkowej duszy słowiańskiej z Ballet russes i powieści Dostojewskiego", zaś "poeci zaczęli sławić międzynarodowe ekspresy i jeden z nich napisał poemat Prose du Transsibérien" (Miłosz 2011b: 946) - chodzi, oczywiście, o Blaise'a Cendrarsa. W tym kontekście interesująca wydaje się uwaga Szumnej na temat Mojego wieku, tomu rozmów Miłosza z Aleksandrem Watem. Otóż stwierdza ona, że książka ta wpłynęła na kształt Kronik. Co więcej, w odniesieniu do wątków rosyjskich można uznać ją za równoważny element autobiograficznego tryptyku (wraz z Rodzinną Europa i Kronikami). Ten wątek, jak sądzę, zasługiwałby na rozwinięcie.

Punktem wyjścia wywodu Szumnej w trzecim rozdziale książki („Literatura polska jest projektem na daleka metę": "prywatne obowiazki” a Miłoszowskie czytanie Rosji) jest tom esejów Prywatne obowiazki (pierwodruk 1972). Autorka, co może wydawać się zaskakujące, na kanwie tych właśnie szkiców snuje rozważania o „Miłoszowskim czytaniu Rosji". Zaskakujące, gdyż w zbiorze tym brak osobnego rozdziału poświęconego tematom rosyjskim, choć oczywiście motywy rosyjskie się przewijają. Miłosz koncentruje się tu przede wszystkim na literaturze polskiej i czyta ją w sposób krytyczny, naruszający tabu, gdyż godzący w - zwłaszcza romantyczne - świętości, w narodową mitologię, co pociąga za sobą również kontestowanie kondycji polskiej inteligencji. Eseista wyraźnie dystansuje się wobec „kanonicznej” polskości. Ta właśnie nieufność wobec polonocentryzmu rodzimej kultury stanowi punkt wyjścia do ujęcia sprawy zasadniczej, acz niewygodnej czy problematycznej w Polsce zniewolonej przez carat a potem zdominowanej przez Rosję sowiecką. Chodzi o potrzebę otwarcia się Polaków na wartości literatury rosyjskiej. Potrafiła ona bowiem stworzyć język, który pozwalał mówić o sprawach uniwersalnych, pryncypialnych, o problemach ostatecznych. Ma niewątpliwie rację autorka, gdy stwierdza:

Miłosz zawsze będzie zwracał uwagę na to, że podstawowa korzyść płynąca z czytania Rosjan to diametralna - i zasadniczo obca jego zdaniem polskiej mentalności - zmiana oglądu rzeczywistości: to po prostu uprzywilejowanie powagi myślenia. Dobra znajomość literatury rosyjskiej - mówi Miłosz - to pewien intelektualny bagaż, który z samej natury wyodrębnia jednostkę spośród tych, którzy takiego zaplecza nie mają. Przede wszystkim daje on narzędzie pozwalające na mniej bezrefleksyjne przyjrzenie się kulturze polskiej, podwyższa poprzeczkę (Szumna 101).

Wyraziste poglądy autora Ziemi Ulro w tej kwestii komentarzem opatrzył Marek Kornat. Zauważał on, że przekonaniom o doniosłości i uniwersalizmie literatury 
i w ogóle myśli rosyjskiej Miłosz „często zwykł był przeciwstawiać uwagi o prowincjonalności polskiego życia intelektualnego", i przytaczał fragmenty listu poety do redaktora „Kultury” (z 1969 roku): „Antologia myśli rosyjskiej niemarksistowskiej, do której powrót w Rosji jest, wcześniej czy później, nieunikniony, byłaby odtrutką na polski zachodniosnobistyczny bełkot oraz na sarmacką brednię i płytkość" (Kornat 34). Zanurzone w filozofii, religii i metafizyce, odznaczające się pryncypialnością, skupiające się na zagadnieniu, ,jak żyć" piśmiennictwo Rosjan stanowi niemałe wyzwanie dla polskich pisarzy. Chciałabym w tym miejscu zacytować znamienne i przekorne słowa zapisane w tomie Nieobjęta ziemia:

Komunizm dał literaturze polskiej niebywałą szansę. Zawsze historycznie zorientowana, ale własną tylko historią zajęta, a więc mało dostępna dla obcych, nagle znalazła się wobec uniwersalnego tematu. Tylko że niewielu piszących wyciągnęło stąd wnioski (Miłosz 2011b: 835).

Myśliciele/pisarze rosyjscy, można dodać, wracając do już podjętych zagadnień, wpisali zagadnienia polityczne $\mathrm{w}$ nurt rozważań o charakterze ponadhistorycznym, odsłaniając metafizyczne kulisy totalitaryzmu. Wart uwagi jest wiersz Lokator o rosyjskim oficerze - samobójcy (Miłosz 2011b:1230).

Szumna zwróciła uwagę na bardzo istotną kwestię (sygnalizowaną tylko pośrednio przez Miłosza), wskazując na istnienie „pewnej formacji kulturalnej, która swoje powstanie zawdzięczała rosyjskiemu systemowi edukacji i dla której balansowanie między dwoma kulturami - polską i rosyjską - bez kategorycznego odrzucania którejkolwiek z nich było stanem naturalnym" (Szumna 99-100). Byli w niej rusofile a jednocześnie polscy patrioci (np. Aleksander Lednicki i jego syn Wacław, rusycysta, o których pisze Miłosz w Prywatnych obowiazkach). Oto Rosja i jej kultura dawała Polakom szansę na dookreślenie się i „wzmocnienie polskiej literatury”.

Badaczka odnosi propozycje Miłosza - które były efektem stanowiska, jakie zajmował wobec kultury rosyjskiej (i polskiej) - do określonej tradycji literackiej; co znamienne, odsuwa na dalszy plan kontekst romantyczny ${ }^{8}$. Czytamy:

8 Na marginesie pokuszę się o dygresję na temat Cypriana Kamila Norwida. Zastanawiam się, czy nie znalazłoby się dla niego miejsce w zestawieniu Szumnej. Miłosz nie pominął go w Prywatnych obowiazkach (172-173), chociaż nie utożsamiał się z norwidowską tradycją (Fiut 85-89). Być może właśnie w tym wypadku skuteczna okazałaby się metoda „kontrolowanej nieufności” w stosunku do deklaracji pisarza. Bardzo interesujący w tym kontekście jest artykuł Edwarda Kasperskiego Wokót „Syberii” Norwida (Kasperski 153-172). Co ciekawe, Miłosz wyobrażał sobie Norwida, ze względu na jego arystokratyzm, jako jednego z Polaków ze Wspomnień z domu umartych (Fiut 88), a także zestawił go z autorem Zbrodni i kary: „[J]eżeli istnieje jakaś esencja polskości, to zawarta jest w Norwidzie, podobnie jak sama esencja rosyjskości zawarła się w Dostojewskim. Norwid i Dostojewski urodzili się w tym samym roku, 1821, i nigdy chyba ziemia nie nosiła równocześnie dwóch mniej podobnych do siebie pisarzy. I mówić tu o ‘duszy słowiańskiej'” (Miłosz 1986: 14). 
„Prywatne obowiązki" - szeroko rozumiane trzeba by rozpatrywać w odniesieniu do trzech możliwych sposobów myślenia o tym, co to znaczy być polskim pisarzem: tradycji podejmowanej (Brzozowskiego), kontrtradycji (Conrada), wreszcie tradycji świadomie zaniechanej (Żeromskiego) (Szumna 111).

W związku z powyższą konstatacją w kolejnym rozdziale Szumna zestawia Miłosza z tymi trzema, jakże różnymi twórcami przełomu XIX i XX wieku, uwzględniając ich stosunek do kwestii rosyjskich. W tej trójce najbardziej oczywiste wydaje sie przywołanie Stanisława Brzozowskiego, któremu Miłosz poświęcił studium Człowiek wśród skorpionów. Badaczka słusznie uwydatnia wpływ autora Legendy Młodej Polski na Miłoszowe lektury Rosjan, na jego otwarcie się na myśl rosyjską, która stanowić może/powinna inspirację do przemyślenia czy przepracowywania polskości i przyjrzenia się krytycznie kulturze polskiej, tak często stroniącej od myślowego wysiłku. Siłą rzeczy Brzozowski stawał się medium dla sądów samego Miłosza. Chciałabym w tym miejscu przytoczyć słowa Franaszka9:

Według Brzozowskiego „uraz antyrosyjski wyjaławiał Polaków intelektualnie i artystycznie, ponieważ przysłaniał im prawdę o kondycji ludzkiej" [cytat z Człowieka wśród skorpionów - E.P.] - komentował poeta, a słowa te można by odnieść i do jego własnych sporów z Giedroyciem o koncentrację "Kultury” na temacie komunizmu i do wielu opinii w Historii literatury polskiej, i wreszcie do zainteresowania Dostojewskim. Przede wszystkim akcentował Miłosz usytuowanie przez Brzozowskiego ludzkiej jednostki w dramatycznej relacji do "pozaludzkiego", przeciwko któremu człowiek wznosi gmach cywilizacji i kultury (Franaszek 597).

Propozycja Szumskiej, aby skonfrontować Miłosza ze Stefanem Żeromskim i Josephem Conradem, może z pozoru (w przeciwieństwie do przywołania Brzozowskiego) wydawać się trudna do zaakceptowania. Autorka dowiodła, że obaj pisarze stanowią wyraziste kontrapunkty dla „rosyjskich” rozpoznań Miłosza.

Pierwszy komponent tytułu kolejnego rozdziału książki („Sybir Europy”. Miłosz, Rosja i wiek XIX) to wymowna figura retoryczna, którą literaturoznawczyni zaczerpnęła z tomu esejów Cezarego Wodzińskiego. Przedwcześnie zmarły filozof - znawca Szestowa i Heideggera - określił tak Rosję. W swej niezwykle obrazowej i ekspresywnej książce „o filozofowaniu siekierą" pisał ${ }^{10}$ :

9 Autorka pominęła w swej książce (również w bibliografii) biografię Miłosza autorstwa Franaszka, ze względu zapewne na gatunkową formę tej publikacji i koncepcję autora. Wydaje mi się jednak, że ta posiadająca bogatą dokumentację książka (a właściwie księga) zasługuje na uwagę również ze względu na podjęcie wątku rosyjskiego.

10 Pozwoliłam sobie zacytować fragment, którego nie ma w przytoczeniu Szumnej. 
Sybir Europy okazał się bezdennie pojemny, wchłonął - pokrywając białym całunem wszystko, co Europa wydalała na skutek prawdziwych lub symulowanych niestrawności. Rosja spełnia(ła) archaiczną funkcję katharsis dla Europy: środka przeczyszczającego na wypadek dolegliwości - zaburzeń i bolączek - wewnętrznych (Wodziński 11).

Szumna w myśli Miłosza odnalazła zaczyn takiego rozumienia roli Rosji, bo jak pisał dalej filozof: „Kłopot z Rosją ma [...] naturę tyle polityczną, co teologiczną” (Wodziński 12). Ze względu na niepojmowalność Rosji i jej nieracjonalność namysł nad nią podlega w eseistyce Miłosza nieustannej repetycji, co stanowi podstawowe założenie omawianej rozprawy, dlatego warto przywołać słowa:

Migotliwość Rosji, fakt, że stanowi ona policzek wymierzony rozumowi wymusza nieustannie ponawiany wysiłek egzegezy, każe raz po raz omawiać te same fakty, co krok próbować nowych zbliżeń - bez pewności, że trud ten zostanie kiedykolwiek wynagrodzony (Szumna 137).

Refleksja nad Rosją, jak wynika z wywodu badaczki, jest też refleksją nad samym sobą, nad kulturą polską i/czyli zachodnią.

Autorka opatruje komentarzami teksty Miłosza z lat pięćdziesiątych (o Bielińskim i Puszkinie). Wówczas - według niej - pisarz odrzucał Rosję, jeszcze nie rozumiał, że kluczem do niej stanie się dlań wiek XIX. Szumna dostrzega w tych narracjach interpretacyjną matrycę, uproszczony tryb lektury, stereotypowość i polityczny wydźwięk. Literaturoznawczyni zwraca uwagę na to, że ważne konteksty do rozpoznania Rosji podsunął Miłoszowi Wat, który „w swoich esejach wyznaczył najważniejsze tematy, przez Miłosza w odniesieniu do Rosji podejmowane" (Szumna 165). Nie chodziło tylko o namysł nad problematyką polityczną, która zresztą miała u Wata metafizyczną podszewkę, ale też o wpływ tłumacza Braci Karamazow na Miłoszową refleksję nad Rosją XIX-wieczną ${ }^{11}$.

Oddzielny passus literaturoznawczyni poświęca kwestii bardzo istotnej, o ile nie kluczowej, czyli stosunkowi Miłosza do twórczości czy - szerzej - filozofii Fiodora Dostojewskiego. W podejściu autora Ziemi Ulro do arcymistrza powieści da się zauważyć dwa aspekty: polityczny i metafizyczny ${ }^{12}$, co znalazło swe odzwierciedlenie w jego wykładach dla amerykańskich studentów. Wyzwanie uniwersyteckie uczyniło polskiego poetę, jak sam siebie określił w rozmowie z Fiutem, „specjalistą od Dostojewskiego" (Fiut 392). Najpierw poeta z Berkeley akcentował problemy natury historyczno-społecznej, potem skupił się na uwypukleniu ich metafizycznego zaplecza. Centralnym punktem rozważań stała się dialektyka wiary i niewiary

11 W sposób bardzo wnikliwy, choć z innym rozłożeniem akcentów niż u Szumnej, rolę Rosji w niefikcjonalnej twórczości Wata i Miłosza ukazał Zbigniew Kopeć (Kopeć 71-86).

12 Pisał na ten temat w bardzo interesującym artykule Tadeusz Sucharski (Sucharski 217). 
tudzież antynomia Boga-Człowieka i Człowieka-Boga. Powieść Dostojewskiego jawiła się polskiemu poecie przede wszystkim jako „instrument wielkiej teologicznej i filozoficznej dysputy" (Miłosz 2010: 87). Szumna sporo uwagi poświęca filozofom rosyjskim ${ }^{13}$, u których Miłosz niejako był "zadłużony”, myślicielom wrażliwym na sprawy eschatologiczne, piętnującym grzechy inteligencji rosyjskiej, dostrzegającym rozłam między nauką a wiarą. Byli wśród nich tacy, którzy (nie bezkrytycznie) kontynuowali myśl podjętą przez Dostojewskiego (Mikołaj Bierdiajew, Lew Szestow).

W ostatnim rozdziale („Rozbieżność rytmu”. Krytyka jako akt translacji) przedmiotem rozważań Szumnej jest zmarginalizowana według niej przez badaczy aktywność krytycznoliteracka Miłosza. Autorka, wnikliwie przyglądając się tej problematyce, zwraca uwagę na ewolucję poglądów poety na przestrzeni czasu: od krytyki interwencyjnej do krytyki wartości. W kontekście wątków rosyjskich zasadnicze znaczenie mają głosy pisarza na temat współczesnej mu literatury i - ogólnie - myśli rosyjskiej (zwłaszcza Borysa Pasternaka i Aleksandra Sołżenicyna), której zresztą poeta przygląda się przez pryzmat pisarstwa XIX-wiecznej Rosji. Szumna, interpretując krytycznoliteracką twórczość Miłosza jako autora tekstów skierowanych głównie do czytelników zachodnich, używa wymownego i bardzo trafnego określenia ",akt translacji”. Literaturoznawczyni zwraca przy tym uwagę na to, że poeta nie był bynajmniej rusofilem. Unikał bezwzględnej aprobaty literatury rosyjskiej, wyczulony zwłaszcza na obecne w niej echa imperializmu i/lub mesjanizmu. Nic dziwnego, pisał przecież: „Gdyby dekabryści zdobyli władzę, w dbałości o utrzymanie imperium [...] przewyższyliby zapewne carów" (Miłosz 2011a: 285). Literatura XX wieku stanowi dlań kontynuacje paradygmatów XIX-wiecznych. W rozdziale piątym Szumna pisała:

Historia literatury rosyjskiej $\mathrm{w}$ jego ujęciu przeradza się $\mathrm{w}$ widmową galerię pisarzy, którzy dziedziczą tę samą obsesję, sam rdzeń myśli - rozdwojenie między współczuciem dla krzywdzonych a chwalbą imperium; to napięcie wyznacza dla Miłosza najważniejszy nurt rosyjskiej kultury, w którym zgodnie kroczą obok siebie Puszkin, Dostojewski, Błok, Mandelsztam, Pasternak, Sołżenicyn, a nawet Majakowski - wszyscy poddani czemuś silniejszemu od nich samych (Szumna 144).

Miłosz jest $\mathrm{w}$ swych enuncjacjach na temat pisarzy rosyjskich bezkompromisowy, przedstawia kontrowersyjne interpretacje, zadaje niewygodne pytania, prowokuje do debaty. Jednakowoż najważniejsza dla niego pozostaje sprawa odniesień literatury rosyjskiej w jej wymiarze uniwersalnym, ogólnoludzkim (ze wszystkimi jej anachronizmami w zakresie rozwiązań literackich) do zdehumanizowanej litera-

13 Chodzi o Mikołaja Bierdiajewa, Władimira Sołowjowa, Sergieja Bułgakowa, Władimira Sołowjowa, Lwa Szestowa i Wasilija Rozanowa. Dwóm ostatnim Miłosz poświęcił oddzielne szkice. 
tury zachodniej, nastawionej głównie na artystyczny eksperyment, a nie na ochronę prymarnych wartości.

Literatura rosyjska więc - jak pisze badaczka - w jej rozwichrzeniu, w niejasności pewnych wyborów i postaw, niezrozumiałych dla nieznającego niektórych jej myślowych przesłanek czytelnika zachodniego - będzie dla Miłosza tak istotnym punktem odniesienia, gdyż stanowi wyzwanie rzucone Zachodowi. Przypomina o tym wszystkim, co w literaturze zachodniej uchodzi za przebrzmiałe [...] (Szumna 206).

Mam wrażenie, że krakowska historyczka literatury, która odcina się z reguły od zastanych ujęć badawczych na temat Rosji Miłosza, wprowadza ciekawe - również polemiczne - sugestie czy koncepcje, ale niewystarczająco je rozwija. Mam tu na myśli na przykład uwagę na temat „zachłyśnięcia” się młodego Miłosza marksizmem, fascynacji „z pozoru szybko odrzuconej” (Szumna 76), a przez dojrzałego eseistę moderowanej przez przywołanie istotnych dlań doświadczeń związanych z wileńskim Instytutem Naukowo-Badawczym Europy Wschodniej ${ }^{14}$.

Chciałabym podjąć jeszcze jeden wątek, który w kontekście rozważań na temat Miłosza i Rosji jest niezwykle istotny. Poeta w rozmowie ze Zbigniewem Podgórcem twierdził, że Dostojewski nie wpłynął na jego twórczość, lecz tylko na sposób odbierania przez niego rzeczywistości (Miłosz 2010: 153). Czy ów brak wpływu miałby dotyczyć kwestii poetyki dzieła? Dostojewski jako diagnostyk erozji wiary religijnej inspirował przemyślenia Miłosza-eseisty, ale oddziaływał też na jego poezję, bo jak pisał Grzegorz Przebinda o jednym z tomów poetyckich: „,[N]ajważniejsze, co łączy Pieska przydrożnego ze światem stworzonym przez autora Braci Karamazow, to nieodparta chęć pokonania historycznego czasu i obrona własnego osobowego «ja» przed kosmicznym Molochem" (Przebinda 228). Odwołam się w tym miejscu do wielce słusznej konstatacji Clare Cavanagh, która pisała, że siłę napędową twórczości zarówno Dostojewskiego, jak i samego Miłosza stanowi pytanie unde malum (Cavanagh 7). Na tej problematyce skupiona jest również filozofia ważnego dla polskiego poety Lwa Szestowa, który, nawiasem mówiąc, uważał Hioba za najważniejszego myśliciela. Oczywiście Szumna nie pomija tej problematyki, skoro traktuje Miłosza przede wszystkim jako pisarza religijnego, który za Brzozowskim kontestował „bezreligijność duszy polskiej”, czyli „brak powagi wobec życia i śmierci” (Miłosz 2011a: 215), i wypowiadał się o Polakach jako o narodzie „rdzennie antymetafizycznym” (Miłosz 2001: 106). Miłosz metafizyczny pochyla się nad Księgą Hioba ${ }^{15}$, która silnie - we-

14 Kornat, powołując się na pochodzący z 1935 roku artykuł Miłosza z tygodnika „Pion”, pisał: „Słowa te interpretować trzeba jako deklarację rezerwy nie tylko wobec takich czy innych programów ideologicznych, lecz także i wobec samej polityki" (Kornat 7).

15 „Dlaczego nie przyznać, że nie postąpiłem w mojej religijności / poza Księgę Hioba? [...] Dzień i noc zwracałem do Boga pytanie: Dlaczego?" ( Miłosz 2011a: 169-127) - pisze poeta w Traktacie teologicznym. 
dług niego - wpłynęła na Dostojewskiego. Echo rozterek bohaterów wykreowanych przez autora Braci Karamazow słyszymy w słowach: „Całe życie próbowałem odpowiedzieć na pytanie: skąd zło? / Niemożliwe, żeby ludzie tak cierpieli, kiedy Bóg jest na niebie i koło mnie" (Miłosz 2011b: 1237). Autor Drugiej przestrzeni nawiązuje też do słynnej frazy Dostojewskiego: "Jeżeli Boga nie ma..." (Miłosz 2011b: 1219, 1350). Ponadto ważne było wpisanie rosyjskiego pisarza w obszar zachodniej wyobraźni religijnej, nie chodzi tylko o Emanuela Swedenborga czy Williama Blake'a, ale też o Simone Weil, której wybór pism Miłosz przełożył i opracował. Tematy te były i będą wciąż podejmowane. Nie sposób ich jednak, czytając Przymus powtórzenia, nie dotknąć, chociaż autorka świadomie nie ujęła tej problematyki w toku swego wywodu, odsyłając czytelników do prac Fiuta i Zbigniewa Kaźmierczyka.

Moje uwagi czy dywagacje na marginesie książki Szumnej dowodzą, że to oryginalne i kompetentne, a także pobudzające do dyskusji studium stanowić może zachętę - nie tylko dla miłoszologów - do ponownego sięgnięcia po inspirujące do przemyśleń dzieło poety-noblisty.

Gdyby Miłosz książkę o Rosji napisał, byłaby ona prawdopodobnie syntezą jego wieloletnich medytacji o świecie historycznym i metafizycznym.

\section{BIBLIOGRAFIA}

Błoński, Jan. Błoński przekorny. Dziennik / Wywiady. Wywiady zebrał i oprac. M. Zaczyński. Kraków: Znak, 2011.

Cavanagh, Clare. „Wstęp. Miłosz i Rosja Dostojewskiego”. Przeł. Agnieszka Pokojska. Rosja. Widzenia transoceaniczne. T. I. Dostojewski - nasz współczesny. Wybór B. Toruńczyk i M. Wójciak, oprac. i układ tomu B. Toruńczyk. Warszawa: Zeszyty Literackie, 2010. S. 5-16.

Miłosz, Czesław. Czesława Miłosza autoportret przekorny. Rozmowy przeprowadził Aleksander Fiut. Kraków: Wydawnictwo Literackie, 1994.

Franaszek, Andrzej. Miłosz. Biografia. Kraków: Wydawnictwo Znak, 2011.

Grudzińska-Gross, Irena. Piętno rewolucji. Custine, Tocqueville i wyobraźnia romantyczna. Przeł. BożenaShallcross. Warszawa: Wydawnictwo Naukowe PWN, 1995.

Janion, Maria. Projekt krytyki fantazmatycznej. Szkice o egzystencjach ludzi i duchów. Warszawa: Wydawnictwo PEN, 1991.

Kasperski, Edward. „Wokół 'Syberii' Norwida. Dwa modele etyki, historiozofii i patriotyzmu”. Kresy, Syberia, literatura. Doświadczenie dialogu i uniwersalizmu. Red. E. Czaplejewicz, E. Kasperski. Warszawa: Trio, 1995. S. 153-172.

Kijowski, Andrzej. Bolesne prowokacje. Poznań: W drodze, 1989.

Kopeć, Zbigniew. „Wat - Rosja - Miłosz”. Porównania 10 (2012). S. 71-86.

Kornat, Marek. „Wstęp. Czesława Miłosz spotkania z Rosją”. Rosja. Widzenia transoceaniczne. Tom II. Mosty napowietrzne. Wybór, oprac. i układ tomu B. Toruńczyk, współpraca M. Wójciak, M. Nowak-Rogoziński. Warszawa: Zeszyty Literackie, 2011. S. 5-53. 
Miłosz, Czesław. „Przypis po latach”. Ziemia Ulro. Kraków: Wydawnictwo Znak, 2013. S. 7-11.

Miłosz, Czesław. Ogród nauk. Lublin: Redakcja Wydawnictw Katolickiego Uniwersytetu Lubelskiego, 1986.

Miłosz, Czesław. Prywatne obowiązki. Kraków: Wydawnictwo Literackie, 2001.

Miłosz, Czesław. Rodzinna Europa. Warszawa: Czytelnik, 1990.

Miłosz, Czesław. Rosja. Widzenia transoceaniczne. T. I. Dostojewski - nasz współczesny. Wybór B. Toruńczyk i M. Wójciak. Oprac. i układ tomu B. Toruńczyk. Warszawa: Zeszyty Literackie, 2010.

Miłosz, Czesław. Rosja. Widzenia transoceaniczne. Tom II. Mosty napowietrzne. Wybór, oprac. i układ tomu B. Toruńczyk, współpraca M. Wójciak, M. Nowak-Rogoziński. Warszawa: Zeszyty Literackie, 2011a.

Miłosz, Czesław. Wiersze wszystkie. Kraków: Znak, 2011 b.

Miłosz, Czesław. Rok myśliwego. Kraków: Znak, 2001.

Przebinda, Grzegorz. Piekło z widokiem na niebo. Spotkania Z Rosją 1999-2004. Kraków: Znak, 2004.

Stala, Marian. Chwile pewności. 20 szkiców o poezji i krytyce. Kraków: Znak, 1991.

Sucharski, Tadeusz. "Miłosz i 'herezje' Dostojewskiego”. Czesława Miłosza "pótnocna strona”. Red. M. Czermińska, K. Szalewska. Gdańsk: Nadbałtyckie Centrum Kultury, [2011]. S. 215-226.

Walicki, Andrzej. Zniewolony umyst po latach. Warszawa: Czytelnik, 1993.

Wodziński, Cezary. Trans, Dostojewski, Rosja czyli O filozofowaniu siekierą. Gdańsk: Słowo/Obraz Terytoria, 2005.

Wójciak, Monika. Enklawy wolności. Literatura rosyjska w Polsce 1956-1989. Kraków: Universitas, 2010. 